\title{
Scale, Scope, and Trade Dynamics of Export Processing Plants*
}

\author{
Ana P. Fernandes ${ }^{\dagger}$ \\ University of Exeter
}

\author{
Heiwai Tang $\ddagger$ \\ Johns Hopkins University
}

April 28, 2015

\begin{abstract}
We use transaction-level data for the universe of Chinese trading firms over 2000-2006 to document that, compared to ordinary exporters, export processing firms are larger but less diversified in products and destinations within the same industry; start exporting larger volumes but grow less over time within a market; are more likely to start selling to more distant markets but less likely to penetrate new ones after the first year. Since EP firms face less uncertainty, these facts can be rationalized in light of the heterogeneous-firm model with uncertainty in export sales, such as Fernandes and Tang (2014).
\end{abstract}

Key Words: export processing, export dynamics, multi-product exporters, margins of trade, global value chains

JEL Classification Numbers: F10, F14

\footnotetext{
${ }^{*}$ We thank an anonymous referee, Emanuel Ornelas, Alan Winters, seminar participants at Sussex and conference participants at the 2011 Econometric Society European Meeting in Oslo for comments.

${ }^{\dagger}$ Email: a.p.o.fernandes@exeter.ac.uk; University of Exeter, Department of Economics, Exeter, EX4 4PU, U.K. (corresponding author).

${ }^{\ddagger}$ Email: hwtang@jhu.edu; School of Advanced International Studies, Johns Hopkins University, Washington, DC 20036, U.S.A.
} 


\section{Introduction}

Many developing countries begin engaging in global trade by assembling imported intermediates into final products for export. This type of trade, which is often referred to as export processing (EP), has been a pivotal part of the East Asian Miracle growth experience and is still widespread around the world. In 2006-2007, EP plants employed an estimated 63 million people worldwide, accounting for the majority of exports from countries that are heavily engaged in global value chains, such as China (see Figure 1), Mexico, and the transition economies of Central and Eastern Europe.

Despite its importance for many countries, empirical evidence about EP firms is scant. Existing literature about exporting firms has focused mostly on non-processing exporters, with interpretations guided by a heterogeneous-firm model about whether, what, and where firms export. EP firms' often receive orders and intermediate inputs from foreign buyers and their export performance can thus differ substantially from the "active" exporters in existing literature. Comparing export performance between countries with different dependence on EP without taking into account their fundamental differences could lead to misguided policies.

We provide systematic evidence about the export patterns and dynamics of EP firms, using transaction-level data for all Chinese trading firms over 2000-2006. The unique feature of the Chinese data is that it distinguishes EP firms from ordinary (non-processing) exporters (OE), while most countries do not separate the two types of exporters. We provide a detailed account of exporters' scale, scope, growth, entry, and transition dynamics, and show that relative to OEs, EP firms (1) are larger in terms of sales, but less diversified in terms of products and destinations; (2) start exporting with a larger volume and (3) grow less over time within a market; (4) are more likely to start selling to more distant markets, but less likely to penetrate into new markets after the first year.

We rationalize these findings in light of recent international trade models of firm heterogeneity, featuring fixed export costs. ${ }^{1}$ Since EP firms typically receive orders from foreign buyers for processing, they are likely to be associated with lower fixed costs and thus on average they should be less productive than OEs (Bernard, Redding and Schott, 2010 and 2011). ${ }^{2}$ This can explain why EP firms export fewer products; and if fixed export costs are increasing in distance and at a lower rate for EP firms, lower fixed costs can also rationalize the fact that EP firms start exporting to more distant markets.

Uncertainty about export prospects can be an additional model feature that is required to

\footnotetext{
${ }^{1}$ See Melitz and Redding (2012) for a literature review.

${ }^{2}$ Manova and Yu (2012) find that EP firms are less productive than OE firms in China.
} 
explain the remaining facts. Existing research finds that exporters often enter new markets with small export sales before expanding substantially (Eaton et al., 2014). Models featuring demand and supply uncertainty facing new exporters have been developed to reconcile these facts (Rauch and Watson, 2003; Albornoz et al., 2012; Eaton et al., 2014). With uncertainty about export performance, firms enter export markets with small orders, to close destinations, to learn about profits. After uncertainty is lifted, they either exit if profits are low or rapidly expand if export profits are high. These dynamics have been theoretically and empirically examined by Fernandes and Tang (2014), which uses the same micro data as this paper but focuses on learning from existing exporters.

Since EP firms receive orders from foreign clients, they are likely to face less uncertainty and less need to "test the ground" as OEs do. This would result in larger initial export sales and lower growth over time. To the extent that export uncertainty is positively related to physical and cultural distance from the destination countries, export sales uncertainty can also explain why EP firms tend to start exporting to more distant markets.

\section{Data}

We use transactions-level data for the universe of Chinese trading firms between 2000 and 2006. The data report values of firm exports and imports in US dollars by product (at 8-digit Harmonized System) and trading partner (over 200 countries). We aggregate observations to the HS 6-digit product level, as the HS 8-digit is country-specific. While the data are available monthly, we focus on annual trade flows.

For each transaction, our data also contain information on quantities, ownership type of firm (e.g. foreign, private, state-owned, collectively owned), region or city in China from where the product was exported, and importantly, customs regime. We use data for processing plants which are classified according to the special customs regimes "Processing and Assembling" and "Processing with Imported Materials". Non-processing trade is classified by China Customs Statistics according to the regime "Ordinary Trade".

Since we study differences in export patterns and dynamics between EP and OEs, we only consider firms that engage exclusively in ordinary exports or export processing in a year. We drop firms that operate in both trade modes in the same year. ${ }^{3}$ We verify that our empirical results are not driven by the exclusion of hybrid exporters. Furthermore, since we are interested in studying export patterns of firms that produce and export, we exclude intermediaries (identified

\footnotetext{
${ }^{3}$ Around $25 \%$ of firms operate in both EP and ordinary-trade regimes in the same year in the sample.
} 
by keywords in companies' names), which are pure import-export companies and do not engage in manufacturing.

\section{Scale and Scope}

Figures 2 and 3 plot the kernel density of the (log) number of products and destinations, respectively. They show that OEs sell more products and to more destinations than EP firms, on average. Figure 4 plots the kernel density of (log) firm exports, and shows that EP firms have a thicker right tail.

To examine more systematically the product and destination scope and the scale of each type of exporters, we estimate specifications of the form:

$$
Y_{i t}=\beta_{1} E P_{i}+\{F E\}+\epsilon_{i t}
$$

Where the dependent variable, $Y_{i t}$, is the number of products exported, the number of destinations served, or the $\log$ of exports by firm $i$ in each year, respectively. $E P_{i}$ is an indicator variable for whether firm $i$ is an EP firm. We include a wide range of fixed effects, denoted by $\{F E\}$. We estimate a negative binomial model for the count variables, bootstrapping standard errors, and additionally controlling for (log) firm lagged total exports $\left(X_{i t-1}\right)$ to proxy for the firm's capability to expand its scope. Results in columns (1) to (4) of Table 1 show that the coefficient on the EP dummy is negative and statistically significant at the $1 \%$ level. The magnitude of the coefficients, controlling for ownership type and for province-industry-year fixed effects to account for time-varying systematic differences across provinces with differential effects across industries (e.g., differences in business environment or policies that may impact certain industries more), implies that EP firms on average export about $27 \%(=\exp (-0.314)-1)$ fewer products and to fewer destinations than OEs.

The positive and statistically significant coefficient on the EP dummy in the remaining columns suggests that EP firms are on average larger than OEs, even within province-industry-years, controlling for ownership. Columns (7) and (8) explore the relationship at the firm-product-country level, controlling for the firm's lagged total exports. An EP firm on average exports 19 percent more than an OE to the same destination, from the same province, in the same year and ownership type. We also confirm that the larger sales of EP firms are not due to higher prices, but higher export quantity. ${ }^{4}$

In sum, within the same industry, province, and ownership type, processing exporters are larger

\footnotetext{
${ }^{4}$ We regress the $(\log )$ unit value at the firm-product-country level on the EP dummy, product-country-year, province and ownership fixed effects. Results are available upon request.
} 
in terms of sales, but less diversified in terms of number of products and destinations. The literature postulates that more productive exporters have larger foreign sales, a wider product range, and serve more countries. To the extent that EP firms are approached by foreign buyers, instead of investing to reach out to them, they may incur lower fixed market costs (Arkolakis, 2010), and face lower export uncertainty, which could rationalize their larger scale and smaller product and country scopes.

\section{Export Dynamics}

Research shows that new exporters often start exporting small volumes, and sales of surviving ones surge in the second year and stabilize growth subsequently. We examine whether EP firms differ in terms of size on entry and growth rates. In Table 2 we regress the log value of firm exports in the first year on the EP dummy variable, and the set of fixed effects. We find that EP firms start exporting with a larger volume than OEs, even within the same industry-province-year. Results at the firm-country level show that EP firms also sell more in a new country, compared to OEs (columns 3 and 4).

Columns (5) and (6) show that EP entrants on average grow less over time than OEs, conditional on survival. These results are consistent with lower export uncertainty facing EP firms, who receive orders directly from foreign buyers, and thus start larger and grow less subsequently, relative to OEs that have more to learn about their export potential from their first year in export markets.

To investigate exporters' market penetration dynamics, we estimate the following linear probability model:

$$
\operatorname{Pr}\left(E_{\text {Entr }} \text { ict }_{1}=1\right)=\gamma_{1} E P_{i}+\gamma_{2} \ln X_{i t-1}+\{F E\}+\epsilon_{i c t},
$$

Where Entry $y_{i c t}$, takes the value of 1 if firm $i$ enters country $c$ at period $t$ and zero otherwise. ${ }^{5}$ Table 3 shows that the probability of entering a new market is lower for EP firms than for OE's. This result is observed within the same year, country-industry-province group, and ownership type, accounting for any supply shocks in year $t-1$ that might affect the firm's decision to enter a new destination in year $t$ (column 5).

Table 4 investigates the effect of distance to the destination on the entry probability. The positive and significant coefficient on lagged firm exports suggests that larger exporters are more likely to enter new destinations. Although distance has a negative effect on entry, EP firms are

\footnotetext{
${ }^{5}$ The estimation sample includes all firms that export to a country for at least 2 years. We drop the firm-country pair from the sample from $t+1$ onwards if Entry ict $=1$ at $t$.
} 
more likely to start exporting to more distant countries (geographically and culturally) relative to OEs, as shown by the positive and significant coefficients on the interaction terms between the EP dummy and distance.

In sum, processing exporters are more likely to start selling to more distant markets, but less likely to penetrate new ones after the first year. If fixed costs of trade are higher for more distant markets, new exporters tend to use closer markets as "testing grounds". If the fixed costs are lower for EP firms, they are less likely to sell to proximate markets before serving more distant ones. To the extent that uncertainty increases with distance to the destination, lower uncertainty facing EP firms can also explain why EP firms tend to start exporting to more distant markets.

\section{Conclusions}

Using data for the universe of Chinese exporters, we show that compared to ordinary exporters, export processing firms are larger but less diversified in products and destinations; start exporting with a larger volume; grow less in the first year and over time within a market; and are more likely to start selling to more distant markets but less likely to penetrate new markets after the first year. We discuss these facts in light of existing trade models with export profit uncertainty incorporated.

These findings suggest that countries relying heavily on processing exports would appear to have more stable aggregate export dynamics. Our findings that EP firms start exporting with large volumes confirm the belief that EP is a safe path for a country to engage in global trade. However, the lower upward mobility of EP firms highlights a trade-off between higher survival rate of new exporters and more dynamic long-run growth supported by established exporters who go through learning. 


\section{References}

1. Albornoz, F., H. Pardo, G. Corcos, E. Ornelas (2012) "Sequential Exporting," Journal of International Economics,

2. Arkolakis, C. (2010) "Market Penetration Costs and the New Consumers Margin in International Trade," Journal of Political Economy, 118(6), 1151-1199.

3. Bernard, A., S. Redding, P. Schott (2010) "Multi-Product Firms and Product Switching," American Economic Review, 100(1), 70-97.

4. Bernard, A., S. Redding, P. Schott (2011) "Multi-Product Firms and Trade Liberalization," Quarterly Journal of Economics, 126(3), 1271-1318.

5. Eaton, J., M. Eslava, D. Jinkins, M. Krizan, M. Kugler, J. Tybout (2014) "A Search and Learning Model of Export Dynamics," mimeo, Penn State University.

6. Fernandes, A., H. Tang (2014) "Learning to Export from Neighbors," Journal of International Economics, 94(1), 67-84.

7. Manova, K., Z. Yu (2013) "Firms along the Value-Added Chain: Processing Trade in China," mimeo, Stanford University.

8. Melitz, M., S. Redding (2012) "Heterogeneous Firms and Trade," forthcoming Handbook of International Economics.

9. Rauch J., Watson M. (2003) "Starting Small in an Unfamiliar Environment," International Journal of Industrial Organization, 21(7), 1021-1042. 


\section{$7 \begin{array}{ll}7 \text { Figures and Tables }\end{array}$}

Figure 1:

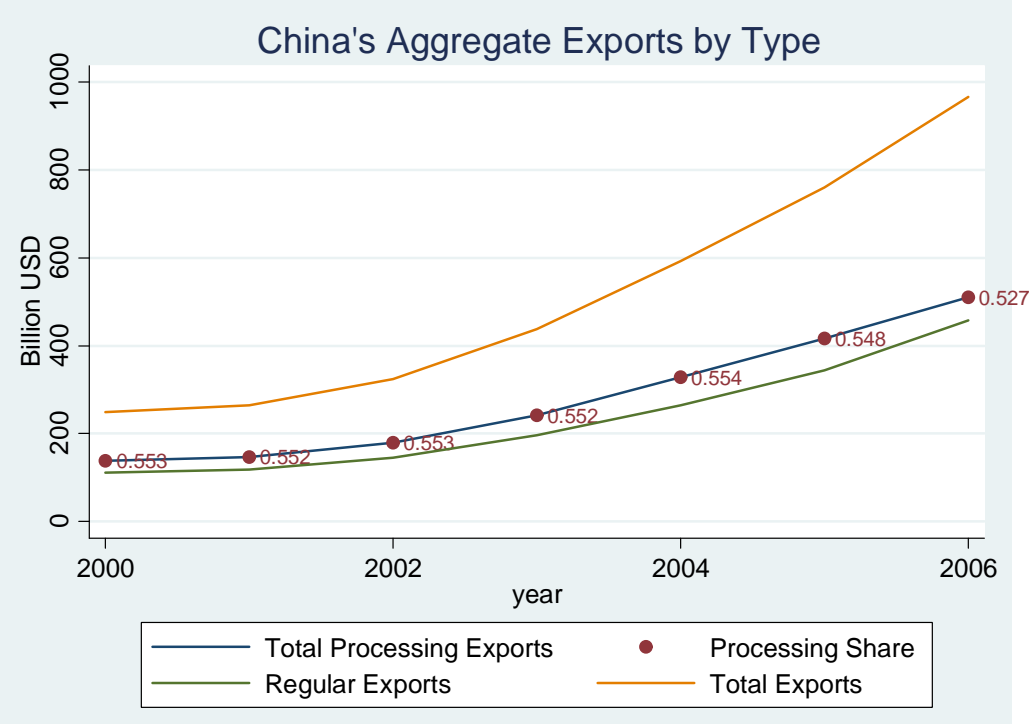


Figure 2:

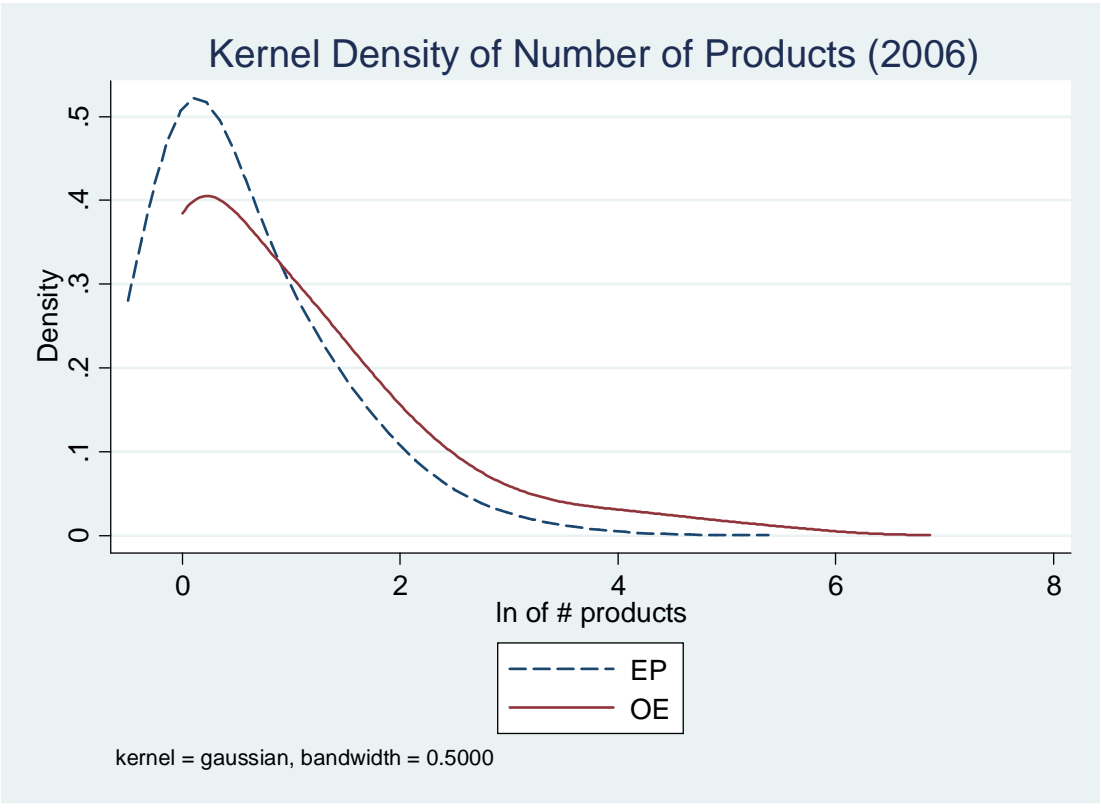

Figure 3:

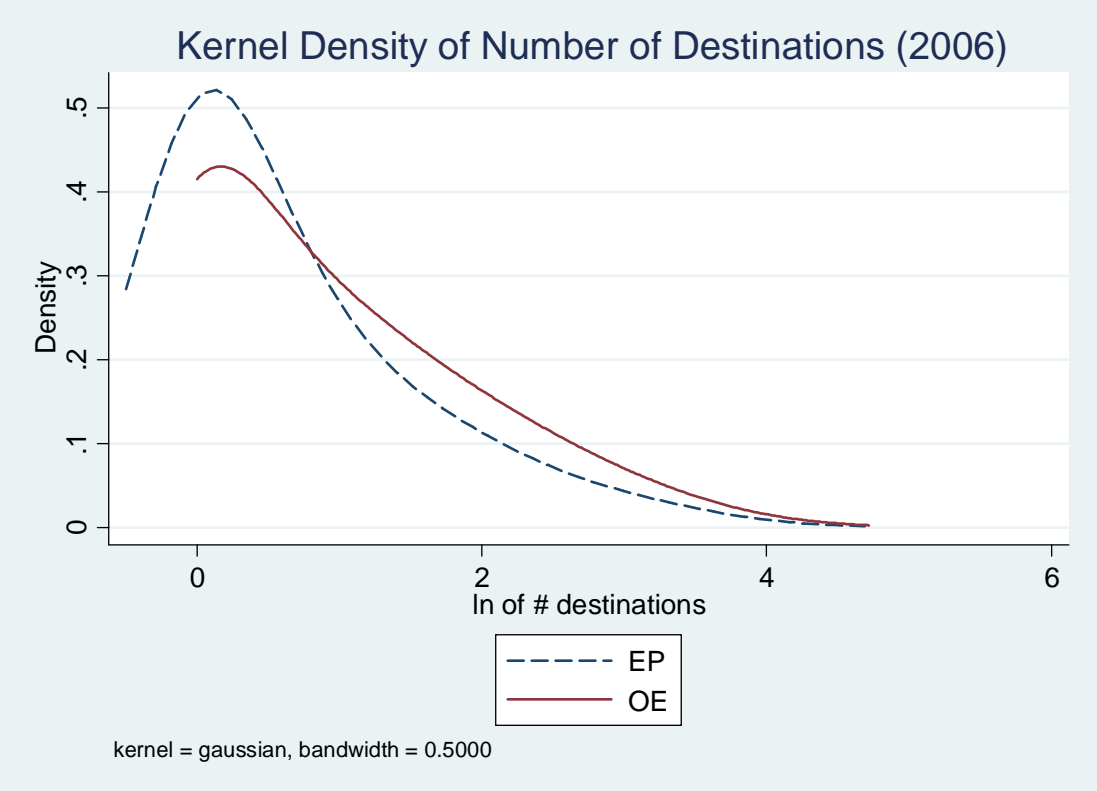


Figure 4:

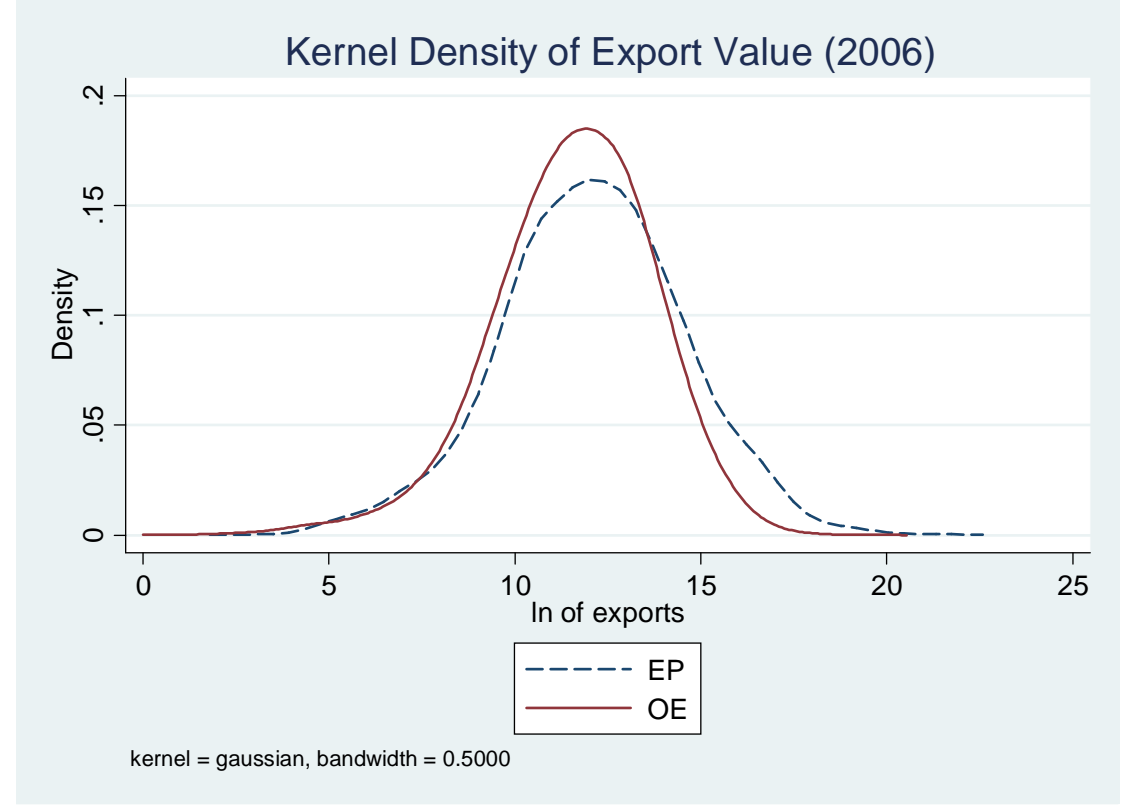

Figure 5:

Table 1: Product and Destination Scope and Export Value

\begin{tabular}{|c|c|c|c|c|c|c|c|c|}
\hline Dep. Variable: & \multicolumn{2}{|c|}{ num. products ${ }_{i t}$} & \multicolumn{2}{|c|}{ num. destinations $i t$} & \multicolumn{2}{|c|}{$\ln \left(\right.$ Exports $\left._{i t}\right)$} & \multicolumn{2}{|c|}{$\ln \left(\right.$ Exports $\left._{i p c t}\right)$} \\
\hline & $(1)$ & $(2)$ & $(3)$ & $(4)$ & $(5)$ & $(6)$ & $(7)$ & $(8)$ \\
\hline Processing & $\begin{array}{c}-0.193 * * * \\
(-12.45)\end{array}$ & $\begin{array}{c}-0.314^{* * *} \\
(-22.39)\end{array}$ & $\begin{array}{c}-0.363^{* * *} \\
(-19.04)\end{array}$ & $\begin{array}{c}-0.321^{* * *} \\
(-23.73)\end{array}$ & $\begin{array}{c}0.856^{* * *} \\
(16.03)\end{array}$ & $\begin{array}{c}0.869^{* * *} \\
(25.99)\end{array}$ & $\begin{array}{c}0.404^{* * *} \\
(16.09)\end{array}$ & $\begin{array}{c}0.186 * * * \\
\quad(4.52)\end{array}$ \\
\hline $\ln$ (firm exports) & $\begin{array}{c}0.103^{* * *} \\
(27.47)\end{array}$ & $\begin{array}{c}0.113^{* * *} \\
(72.04)\end{array}$ & $\begin{array}{c}0.195^{* * *} \\
(64.26)\end{array}$ & $\begin{array}{c}0.182^{* * *} \\
(93.34)\end{array}$ & & & $\begin{array}{c}0.118^{* * *} \\
(53.49)\end{array}$ & $\begin{array}{c}0.202^{* * *} \\
(64.63)\end{array}$ \\
\hline $\begin{array}{l}\text { ownership FE } \\
\text { industrv*var FE }\end{array}$ & yes & yes & yes & yes & yes & yes & yes & yes \\
\hline $\begin{array}{l}\text { industry* country*year FE } \\
\text { province*industry* year FE } \\
\text { province*country*year FE }\end{array}$ & & yes & & yes & $y=0$ & yes & yes & yes \\
\hline $\begin{array}{l}\text { Nb. Obs. } \\
\text { ll/ R-sq }\end{array}$ & $\begin{array}{c}286205 \\
-834731\end{array}$ & $\begin{array}{c}248423 \\
-584843\end{array}$ & $\begin{array}{c}286205 \\
-798729\end{array}$ & $\begin{array}{c}248423 \\
-622334\end{array}$ & $\begin{array}{c}473115 \\
.0446\end{array}$ & $\begin{array}{c}416330 \\
.0479\end{array}$ & $\begin{array}{c}4910131 \\
.0405\end{array}$ & $\begin{array}{c}2880367 \\
.0334\end{array}$ \\
\hline
\end{tabular}

Products are HS 6-digit categories. Processing is an indicator variable for whether firm i is an EP firm. In columns 1-4, we use a negative binomial model for the count dependent variables, and bootstrap the stand errors. $t$ statistics are reported in parentheses. Standard errors are robust and clustered at the level of the fixed effects included, other than ownership in columns $5-8$; results are robust to alternative levels of clustering. ${ }^{* * *},{ }^{* *}$, and ${ }^{*}$ indicate significance at the 1,5 , and 10 percent level, respectively. 
Table 2: Export Value at Entry and Export Growth

\begin{tabular}{|c|c|c|c|c|c|c|}
\hline \multirow[t]{2}{*}{ Dep Variable: } & \multicolumn{2}{|c|}{$\ln \left(\right.$ Exports $\left._{i t}^{0}\right)$} & \multicolumn{2}{|c|}{$\ln \left(\operatorname{Exports}_{i c t}^{0}\right)$} & \multicolumn{2}{|c|}{ Export growth $_{i t}$} \\
\hline & $(1)$ & $(2)$ & $(3)$ & (4) & $(5)$ & $(6)$ \\
\hline Processing & $\begin{array}{c}0.758^{* * *} \\
(10.92)\end{array}$ & $\begin{array}{c}0.752^{* * *} \\
(17.83)\end{array}$ & $\begin{array}{l}0.290^{* * *} \\
\quad(6.96)\end{array}$ & $\begin{array}{c}0.257^{* * *} \\
(11.16)\end{array}$ & $\begin{array}{c}-27.24^{* * *} \\
(-3.62)\end{array}$ & $\begin{array}{c}-15.79 * * \\
(-2.16)\end{array}$ \\
\hline ownership FE & yes & yes & yes & yes & yes & yes \\
\hline industry*year FE & yes & & Yo & & yes & \\
\hline $\begin{array}{l}\text { province*ind.*year FE } \\
\text { province* country*year FE }\end{array}$ & & yes & & yes & & yes \\
\hline $\mathrm{N}$ & 186906 & 165282 & 1451015 & 1044881 & 271545 & 237625 \\
\hline R-sq & .0381 & .0408 & .0042 & .0029 & .0064 & .0101 \\
\hline
\end{tabular}

Observations are at firm-country-year in columns (3) and (4) and at firm-year in the remaining columns. t statistics are reported in parenthesis. Standard errors are robust and clustered at the level of the fixed effects included, other than ownership and year. Results are robust to alternative levels of clustering. ${ }^{* * *},{ }^{* *}$, and ${ }^{*}$ indicate significance at the 1,5 , and 10 percent level, respectively.

Table 3: Probability of Exporting to a New Country

\begin{tabular}{|c|c|c|c|c|c|}
\hline \multirow[t]{2}{*}{ Dep. Variable: } & \multicolumn{5}{|c|}{ Entry $_{i c t}$ (Binary) } \\
\hline & (1) & $(2)$ & $(3)$ & $(4)$ & $(5)$ \\
\hline Processing & $\begin{array}{c}-0.0021^{* * *} \\
(-8.98)\end{array}$ & $\begin{array}{c}-0.0025^{* * *} \\
(-22.26)\end{array}$ & $\begin{array}{c}-0.0024^{* * *} \\
(-27.45)\end{array}$ & $\begin{array}{c}-0.0036^{* * *} \\
(-26.85)\end{array}$ & $\begin{array}{c}-0.0039 * * * \\
(-39.46)\end{array}$ \\
\hline $\ln$ (firm exports) & & & & $\begin{array}{c}0.0011^{* * *} \\
(50.29)\end{array}$ & $\begin{array}{c}0.0013^{* * * *} \\
(78.79)\end{array}$ \\
\hline $\begin{array}{l}\text { ownership FE } \\
\text { country*year FE }\end{array}$ & $\begin{array}{l}\text { yes } \\
\text { yes }\end{array}$ & yes & yes & yes & yes \\
\hline $\begin{array}{l}\text { country* province* }{ }^{*} \text { year FE } \\
\text { country*industry* province FE } \\
\text { year FE }\end{array}$ & & yes & $\begin{array}{l}\text { yes } \\
\text { yes }\end{array}$ & yes & $\begin{array}{l}\text { yes } \\
\text { yes }\end{array}$ \\
\hline $\begin{array}{l}\mathrm{N} \\
\mathrm{R} \text {-sq }\end{array}$ & $\begin{array}{c}113023768 \\
.00182\end{array}$ & $\begin{array}{c}104860407 \\
.00108\end{array}$ & $\begin{array}{c}104860407 \\
.00153\end{array}$ & $\begin{array}{l}52538615 \\
.00175\end{array}$ & $\begin{array}{c}52538615 \\
.00248\end{array}$ \\
\hline
\end{tabular}

This table estimates a linear probability model of market entry. Standard errors are robust and clustered at the level of the fixed effects included, other than ownership and year. Results are robust to alternative levels of clustering. ${ }^{* * *}, * *$, and $*$ indicate significance at the 1,5 , and 10 percent level, respectively. 
Table 4: Probability of Exporting to a New Country and Country Characteristics

\begin{tabular}{|c|c|c|c|c|}
\hline Dep. Variable: & \multicolumn{2}{|c|}{ Entry $_{i c t}$ (Binary) } & \multicolumn{2}{|c|}{ Entry $_{i c t}$ (Binary) } \\
\hline Country Char. (Z) & $\ln ($ dist $)$ & $\ln ($ g. dist $)$ & $\ln ($ dist $)$ & $\ln (\mathrm{g}$. dist $)$ \\
\hline & $(1)$ & $(2)$ & $(3)$ & $(4)$ \\
\hline Processing*Z & $\begin{array}{c}0.00466^{* * *} \\
(23.44)\end{array}$ & $\begin{array}{c}0.00544^{* * *} \\
(19.65)\end{array}$ & $\begin{array}{c}0.00316^{* * *} \\
(16.89)\end{array}$ & $\begin{array}{c}0.00357^{* * *} \\
\quad(13.94)\end{array}$ \\
\hline Foreign*Z & & & $\begin{array}{c}0.00345^{* * *} \\
(22.66)\end{array}$ & $\begin{array}{c}0.00428^{* * *} \\
(21.86)\end{array}$ \\
\hline $\mathrm{Z}$ & $\begin{array}{c}-0.00814^{* * *} \\
(-56.42)\end{array}$ & $\begin{array}{c}-0.0102^{* * *} \\
(-49.88)\end{array}$ & $\begin{array}{c}-0.00990^{* * *} \\
(-53.19)\end{array}$ & $\begin{array}{c}-0.0124^{* * *} \\
(-46.23)\end{array}$ \\
\hline Processing & $\begin{array}{c}-0.0467^{* * *} \\
(-25.69)\end{array}$ & $\begin{array}{c}-0.0433^{* * *} \\
(-21.81)\end{array}$ & $\begin{array}{c}-0.0334^{* * *} \\
(-19.66)\end{array}$ & $\begin{array}{c}-0.0302^{* * *} \\
(-16.63)\end{array}$ \\
\hline Foreign & & & $\begin{array}{c}-0.0362^{* * *} \\
(-24.67)\end{array}$ & $\begin{array}{c}-0.0356^{* * *} \\
(-23.42)\end{array}$ \\
\hline $\ln$ (firm exports) & $\begin{array}{c}0.00130 * * * \\
(33.05)\end{array}$ & $\begin{array}{c}0.00127^{* * *} \\
(32.85)\end{array}$ & $\begin{array}{c}0.00126 * * * \\
(32.86)\end{array}$ & $\begin{array}{c}0.00123^{* * *} \\
\quad(32.66)\end{array}$ \\
\hline $\begin{array}{l}\text { ownership FE } \\
\text { Province*industry*year FE }\end{array}$ & $\begin{array}{l}\text { yes } \\
\text { yes }\end{array}$ & $\begin{array}{l}\text { yes } \\
\text { yes }\end{array}$ & yes & yes \\
\hline $\mathrm{N}$ & 37415780 & 34105716 & 37415780 & 34105716 \\
\hline r2 & .00305 & .00451 & .00283 & .00436 \\
\hline
\end{tabular}

This table investigates the effect of distance to the destination on the entry probability. We drop exports to Hong Kong and Macao as their geographic and cultural distance to China is essentially zero. We include measures for geographic and cultural distance as well as the interaction terms between the distance measures and the EP dummy (Processing). In columns (3) and (4) we further include interaction terms between a foreign ownership dummy and distance to account for the fact that foreign ownership prevails in EP trade, and investigate if the differential effect of distance on EP firms remains beyond that of foreign ownership. $t$ statistics are reported in parentheses. Standard errors are robust and clustered by province-industry-year. Results are robust to alternative levels of clustering. $* * *, * *$, and $*$ indicate significance at the 1,5 , and 10 percent level, respectively. 